\title{
Two [2]pseudorotaxane-like complexes and their corresponding [2]rotaxanes stabilized via interactions on opposite ends of the same macrocycle
}

\author{
Wei-Chung Hung ${ }^{a}$, Liang-Yun Wang ${ }^{a}$, Chien-Chen Lai ${ }^{b}$, Yi-Hung Liu ${ }^{a}$, \\ Shie-Ming Peng ${ }^{\mathrm{a}}$, Sheng-Hsien Chiu ${ }^{\mathrm{a}, *}$ \\ a Department of Chemistry, National Taiwan University, No. 1, Sec. 4, Roosevelt Road, Taipei 10617, Taiwan, ROC \\ ${ }^{\mathrm{b}}$ Institute of Molecular Biology, National Chung Hsing University and Department of Medical Genetics, China Medical University Hospital, Taichung, Taiwan, ROC
}

\section{A R T I C L E I N F O}

Article history:

Received 21 August 2008

Revised 10 October 2008

Accepted 10 October 2008

Available online 7 November 2008

\begin{abstract}
A B S T R A C T
A multiple-use macrocycle recognizes dibenzylammonium ions and 2,6-lutidine derivatives, each in a [2]pseudorotaxane-like manner, through interactions with its diethylene glycol (hydrogen bonding) and 2,6-pyridinedicarboxamide ( $\mathrm{Pd}^{2+}$ chelation) spacers, respectively. We characterized these complexes in the solid state (X-ray crystallography) and in solution ( ${ }^{1} \mathrm{H}$ NMR spectroscopy). The synthesis of two corresponding [2]rotaxanes confirmed that these recognition systems possess [2]pseudorotaxane geometries in solution.
\end{abstract}

(c) 2008 Elsevier Ltd. All rights reserved.

Rotaxanes and catenanes attract a great deal of attention because of their potential for applications in mesoscale devices and molecular machinery on the nanoscale. ${ }^{1}$ The synthesis of these interlocked systems usually requires the recognition of a macrocyclic unit by a recognition unit on a threadlike component. ${ }^{2}$ For the realization of interlocked molecular switches and actuators, however, more than one type of recognition site is generally needed to allow itinerant migration of the macrocycle(s) between different recognition sites under the influence of an external stimulus; this binding must not only be discriminative but also sufficiently strong at each of these recognition stations. ${ }^{3}$ Nevertheless, macrocycles that can recognize more than one type of guest in a pseudorotaxane-like manner in solution with reasonable binding affinity are relatively rare. The crown ethers dibenzo[24]crown-8 (DB24C8) and bis-p-phenylene[34]crown-10 (BPP34C10) are particularly notable examples that have been used to construct several molecular switches because they can recognize several guests-dibenzylammonium ions $\left(\mathrm{DBA}^{+}\right),{ }^{4}$ 1,2-bis(pyridinium)ethane units, ${ }^{5}$ or bipyridinium dications ${ }^{6}$-in [2]pseudorotaxane-like geometries in solution with sufficiently high binding affinities. Intuitively, dualor multiple-use macrocycles for future supramolecular catalytic systems or for the preparation of sensitive molecular switches can be developed by linking two or more different recognition systems as loops within a single macrocycle. The design of such a system requires a delicate balance in the molecular structure to ensure that both recognition systems operate independently. Previously, we reported that macrocycle $\mathbf{1}$, which possesses two xylyl

\footnotetext{
* Corresponding author.

E-mail address: shchiu@ntu.edu.tw (S.-H. Chiu).
}

rings linked by diethylene glycol and 2,6-pyridinedicarboxamide spacers, acts as a host molecule that complexes diphenylurea derivatives through the cooperative interactions with its two opposing recognition units. ${ }^{7}$ Herein, we report that the opposing diethylene glycol and 2,6-pyridinedicarboxamide units of this macrocycle also act independently to recognize both the $\mathrm{DBA}^{+}$ ion and 2,6-lutidine in solution.

In an earlier study, we found that the recognition of a $\mathrm{DBA}^{+}$ion requires a macrocycle featuring only one diethylene glycol chain and two phenolic rings. ${ }^{8}$ Because the 2,6-pyridinedicarboxamide motif places the two phenolic rings a suitable distance apart for

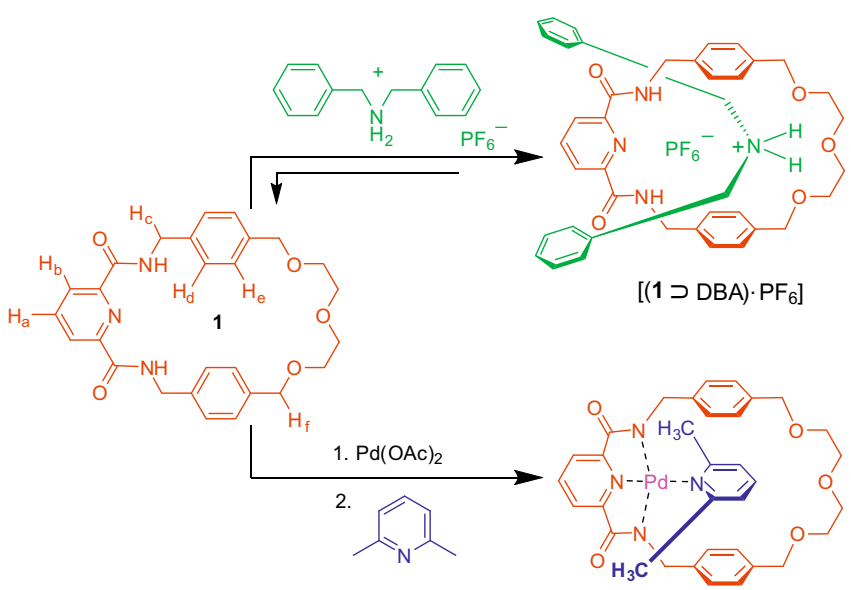

Scheme 1. 
the binding of a guest, ${ }^{9}$ we suspected that macrocycle $\mathbf{1}$ (Scheme 1 ) would form a pseudorotaxane-like complex with the $\mathrm{DBA}^{+}$ion, stabilized primarily through $\left[\mathrm{N}^{+}-\mathrm{H} \cdots \mathrm{O}\right]$ and $\left[\mathrm{N}^{+} \mathrm{C}-\mathrm{H} \cdots \pi\right]$ interactions.

The ${ }^{1} \mathrm{H}$ NMR spectrum of an equimolar $(10 \mathrm{mM})$ mixture of macrocycle 1 and DBA.PF ${ }_{6}$ in $\mathrm{CD}_{3} \mathrm{NO}_{2}$ at room temperature displays changes in the chemical shifts of the protons of the complex relative to those of its free components (Fig. 1); these time-averaged signals suggest that the rates of complexation and decomplexation of $\mathbf{1}$ and $\mathrm{DBA}^{+}$are rapid under these conditions. The spectrum of the complex reveals an upfield shift of the signal for the protons of the benzylic methylene groups adjacent to the $\mathrm{NH}_{2}{ }^{+}$center of the $\mathrm{DBA}^{+}$ion as well as a separation of the 'tight' multiplet $(\delta 3.52-3.62)$ for the methylene protons of the $\mathrm{OCH}_{2-}$ $\mathrm{CH}_{2} \mathrm{O}$ units of the free macrocycle into two signals ( $\delta 3.41$ and $\delta$ 3.62) for the complex; these features suggest the existence of $\left[\mathrm{N}^{+}-\mathrm{H} \cdots \mathrm{O}\right]$ and $\left[\mathrm{N}^{+} \mathrm{C}-\mathrm{H} \cdots \pi\right]$ hydrogen bonds between macrocycle 1 and the $\mathrm{DBA}^{+}$ion. ${ }^{8}$ Accordingly, we suspected the [2]pseudorotaxane-like assembly $\left[\mathbf{1} \supset \mathrm{DBA}^{+}\right]$(Scheme 1 ) to be the likely structure of the complex formed between 1 and the $\mathrm{DBA}^{+}$ion in $\mathrm{CD}_{3} \mathrm{NO}_{2}$. From a ${ }^{1} \mathrm{H}$ NMR spectroscopic dilution experiment, we determined the association constant $\left(K_{\mathrm{a}}\right)$ for this complex in $\mathrm{CD}_{3} \mathrm{NO}_{2}$ to be $330 \pm 30 \mathrm{M}^{-1} \cdot{ }^{10}$

We grew single crystals suitable for X-ray crystallography through liquid diffusion of $i \mathrm{Pr}_{2} \mathrm{O}$ into a $\mathrm{CH}_{3} \mathrm{NO}_{2}$ solution of macrocycle 1 and DBA.PF . The solid state structure $^{11,12}$ (Fig. 2) reveals a [2]pseudorotaxane-like molecular geometry for the complex $\left[\mathbf{1} \supset \mathrm{DBA}^{+}\right]$; it also indicates that the complex is stabilized through both $\left[\mathrm{N}^{+}-\mathrm{H} \cdots \mathrm{O}\right]$ hydrogen bonds and $\left[\mathrm{N}^{+} \mathrm{C}-\mathrm{H} \cdots \pi\right]$ interactions (the distances between the phenolic rings' centroids and the sandwiched methylene carbons are both around $3.6 \AA$ ).

This result confirms our previous finding ${ }^{8}$ that, with suitable design, weak noncovalent interactions can be harnessed to play extremely important roles in stabilizing macrocycle/dialkylammonium ion complexes.

To confirm the existence of the [2]pseudorotaxane $\left[\left(1 \supset \mathrm{DBA}^{+}\right]\right.$in solution, we constructed a [2]rotaxane based on this recognition system. Adding triethyl phosphite $(200 \mathrm{mM})$ to a solution of the benzylic azide $2-\mathrm{H} \cdot \mathrm{PF}_{6}(100 \mathrm{mM})$ and macrocycle $\mathbf{1}(150 \mathrm{mM})$ in $\mathrm{CH}_{2} \mathrm{Cl}_{2}$ gave the corresponding rotaxane, which dissociated slowly during the purification process, presumably because the stoppering groups were not bulky enough. ${ }^{13}$ Indeed, when we added tributyl phosphite under otherwise identical conditions, we isolated

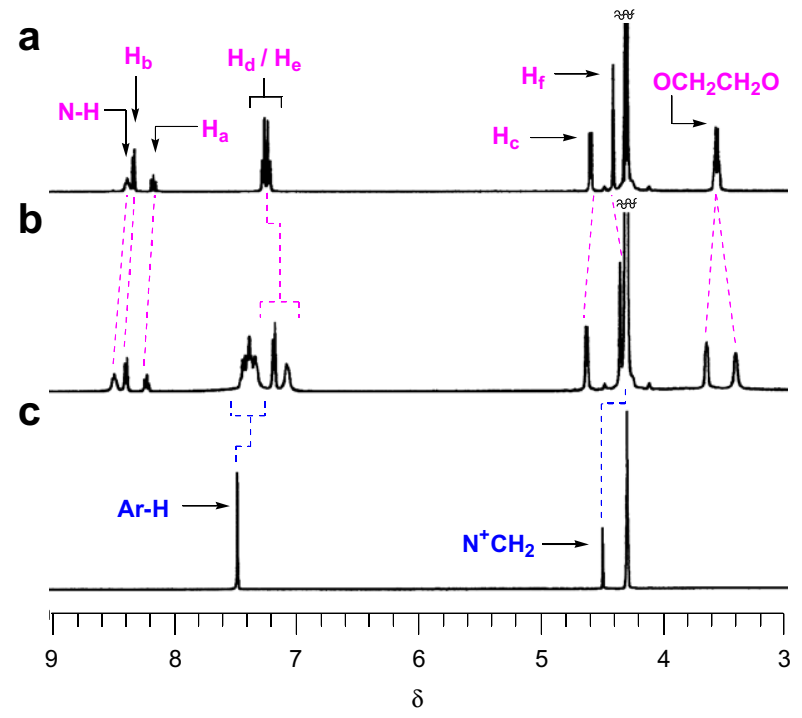

Figure 1. Partial ${ }^{1} \mathrm{H}$ NMR spectra ( $400 \mathrm{MHz}, \mathrm{CD}_{3} \mathrm{NO}_{2}, 298 \mathrm{~K}$ ) of (a) macrocycle 1, (b) an equimolar mixture of 1 and DBA.PF $(10 \mathrm{mM})$, and (c) $\mathrm{DBA}_{6} \cdot \mathrm{PF}_{6}$. a

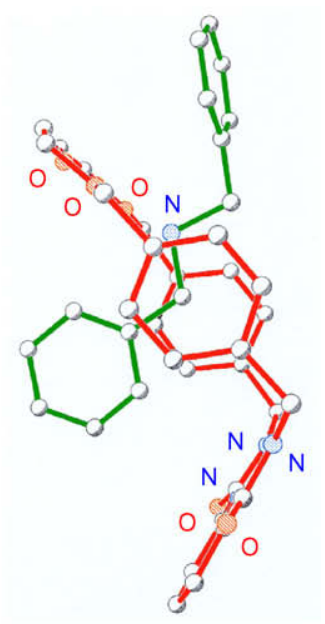

b

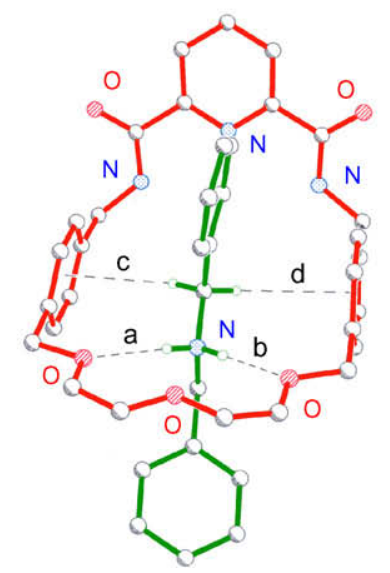

Figure 2. (a) Top and (b) side views of the solid state structure of the [2]pseudorotaxane $\left[\mathbf{1} \supset \mathrm{DBA}^{+}\right]$. The hydrogen bonding geometries, $\mathrm{D} \cdots \mathrm{A}, \mathrm{H} \cdots \mathrm{A}[\AA \AA]$, and $\mathrm{D}-\mathrm{H} \cdots \mathrm{A}$ [ ${ }^{\circ}$ : (a) 2.98, 2.11, 168.9; (b) 2.88, 2.00, 174.1; (c) 3.64, 2.97, 135.5; (d) 3.72, 2.75, 152.0. $\mathrm{D}=$ hydrogen bond donor, $\mathrm{A}=$ hydrogen bond acceptor.

the [2] rotaxane $3-\mathrm{H} \cdot \mathrm{PF}_{6}$ in $23 \%$ yield (Scheme 2$) .{ }^{14}$ After dissolving the phosphoramidate-stoppered [2] rotaxane $3-\mathrm{H} \cdot \mathrm{PF}_{6}$ in $\mathrm{CD}_{3} \mathrm{SOCD}_{3}$, we observed no signals for the free macrocycle 1 in the ${ }^{1} \mathrm{H}$ NMR spectrum, confirming the interlocked nature of its components (Fig. 3). To test the thermal stability of $3-\mathrm{H} \cdot \mathrm{PF}_{6}$, we heated this

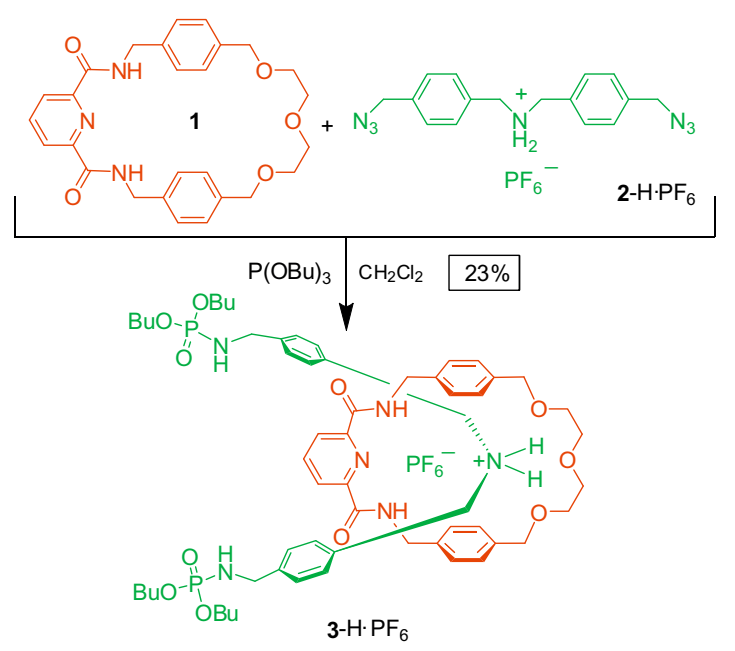

Scheme 2. 
a

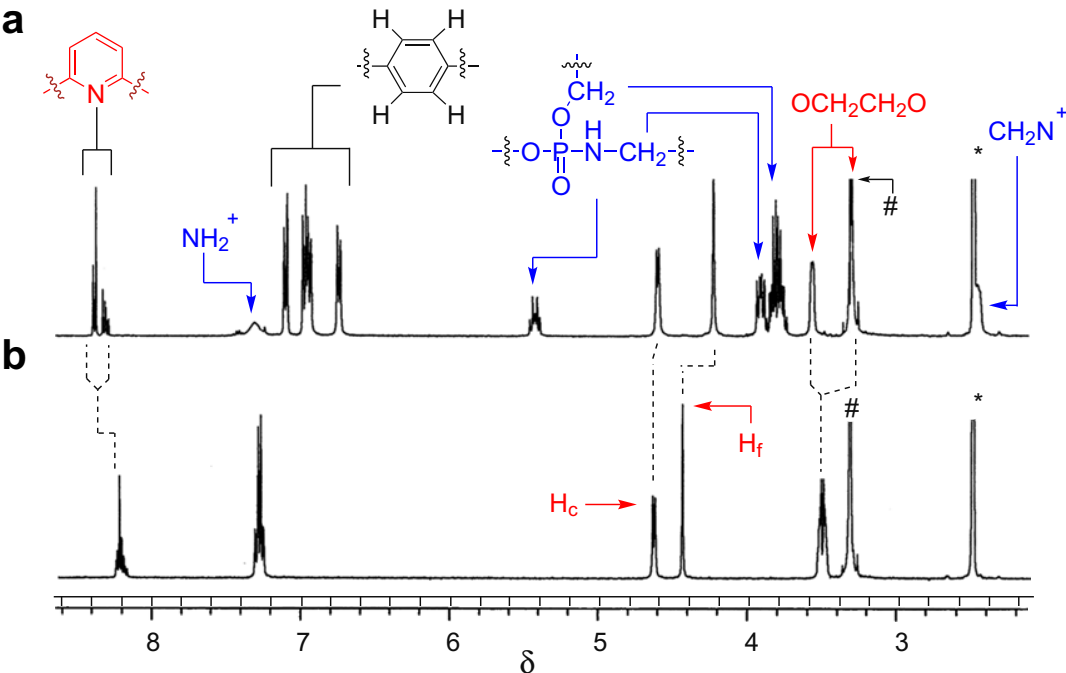

Figure 3. Partial ${ }^{1} \mathrm{H}$ NMR spectra $\left(400 \mathrm{MHz}, \mathrm{CD}_{3} \mathrm{SOCD}_{3}, 298 \mathrm{~K}\right)$ of (a) the [2]rotaxane 3-H.PF $\mathrm{P}_{6}$ and (b) macrocycle 1. \#: The signal of $\mathrm{H}_{2} \mathrm{O}$.

solution at $323 \mathrm{~K}$ while monitoring its ${ }^{1} \mathrm{H}$ NMR spectra. Again, we did not observe any signals for the free macrocycle within $2 \mathrm{~h}$, suggesting that the dibutyl phosphoramidate groups are stoppers that can mechanically interlock the macrocycle $\mathbf{1}$ along the rodlike component of the dumbbell-shaped moiety.

Having proved that the diethylene glycol unit appended to the two aromatic rings in $\mathbf{1}$ was capable of complexing $\mathrm{DBA}^{+}$ions in $\mathrm{CD}_{3} \mathrm{NO}_{2}$, we turned our attention to the complexing behavior of the opposing 2,6-pyridinedicarboxamide moiety, which is known to complex lutidine units via chelation of palladium(II). ${ }^{15}$ Thus, we treated macrocycle 1 with $\mathrm{Pd}(\mathrm{OAc})_{2}$ in $\mathrm{CH}_{3} \mathrm{CN}$ for $3 \mathrm{~h}$ at room temperature to afford (Scheme 3 ) the corresponding $\mathrm{Pd}(\mathrm{II}) \mathrm{com}$ plex 4 (75\% yield), which we then mixed with 2,6-lutidine in $\mathrm{CHCl}_{3}$ to produce the $\mathrm{Pd}(\mathrm{II})$ complex $\mathbf{5}$ in quantitative yield. We obtained single crystals suitable for X-ray crystallography upon liquid diffu-

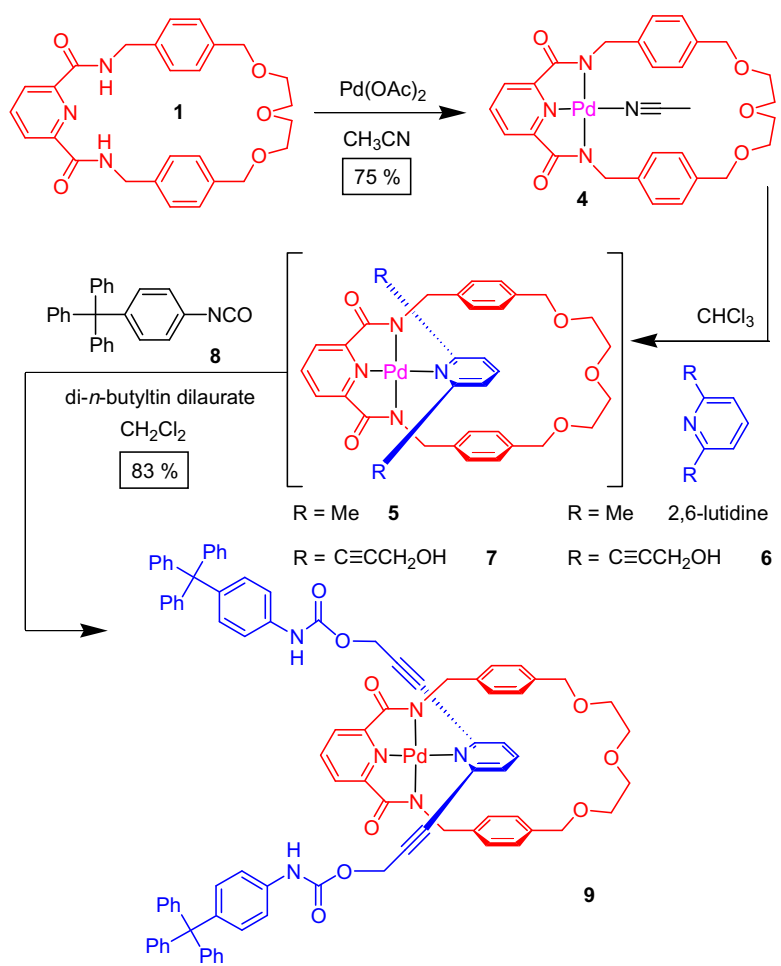

Scheme 3. sion of $i \operatorname{Pr}_{2} \mathrm{O}$ into a $\mathrm{CH}_{3} \mathrm{CN}$ solution of complex 5. The solid state structure $^{16}$ reveals (Fig. 4) a [2]pseudorotaxane-like molecular geometry in which the $\mathrm{Pd}(\mathrm{II})$ atom holds the 2,6-lutidine and 2,6-pyridinedicarboxamide units together with their aromatic planes aligned perpendicularly.

To construct a [2] rotaxane based on this recognition system, we reacted the diol 6 with the $\mathrm{Pd}(\mathrm{II})$ complex 4 in $\mathrm{CHCl}_{3}$ to generate the [2]pseudorotaxane complex $\mathbf{7}$ presenting hydroxyl groups at its termini. Reacting complex 7 with the bulky isocyanate 8 in the presence of di-n-butyltin dilaurate in $\mathrm{CH}_{2} \mathrm{Cl}_{2}$ at room temperature led us to isolate the [2]rotaxane $\mathbf{9}$ in $83 \%$ yield after column chromatography (Scheme 3 ). ${ }^{17}$ The successful preparation of this [2]rotaxane suggests that the 2,6-pyridinedicarboxamide unit within macrocycle $\mathbf{1}$ is capable of recognizing pyridine derivatives such as $\mathbf{6}$ in a pseudorotaxane-like manner in solution under the templating influence of $\mathrm{Pd}(\mathrm{II}){ }^{18}$

a

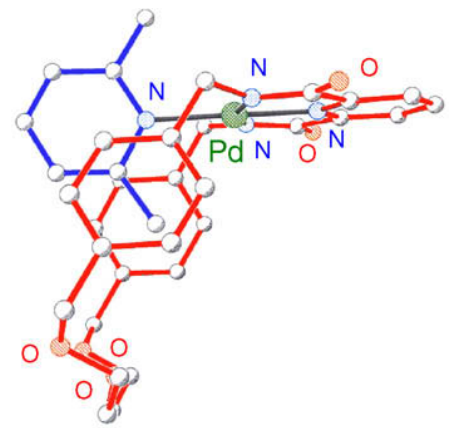

b

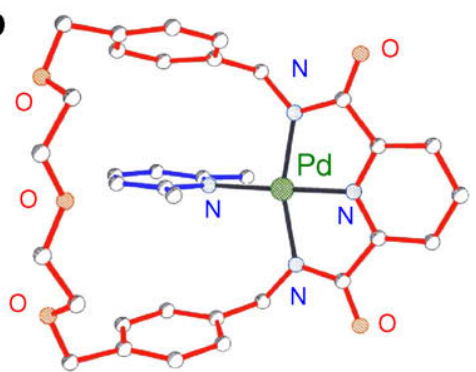

Figure 4. (a) Top and (b) side views of the solid state structure of complex $\mathbf{5}$. 
Macrocycle $\mathbf{1}$ is a multiple-use macrocycle that recognizes diphenylurea, $\mathrm{DBA}^{+}$, and 2,6-lutidine derivatives through interactions with either its diethylene glycol or $\mathrm{Pd}^{2+}$-chelated 2,6-pyridine diamide moieties. The solid state structure of $\left[\mathbf{1} \supset \mathrm{DBA}^{+}\right]$confirmed that $\left[\mathrm{N}^{+} \mathrm{C}-\mathrm{H} \cdots \pi\right]$ interactions play an important role in stabilizing this complex. We aim to use multiple-guest-binding hosts such as $\mathbf{1}$ as components of future molecular catalytic systems and controllable molecular switches.

\section{Acknowledgment}

We thank the National Science Council for financial support (NSC 95-2113-M-002-016-MY3).

\section{References and notes}

1. (a) Collier, C. P.; Mattersteig, G.; Wong, E. W.; Luo, Y.; Beverly, K.; Sampaio, J.; Raymo, F. M.; Stoddart, J. F.; Heath, J. R. Science 2000, 289, 1172-1175; (b) Saha, S.; Leung, K. C.-F.; Nguyen, T. D.; Stoddart, J. F.; Zink, J. I. Adv. Funct. Mater. 2007, 17, 685-693; (c) Green, J. E.; Choi, J. W.; Boukai, A.; Bunimovich, Y.; JohnstonHalperin, E.; DeIonno, E.; Luo, Y.; Sheriff, B. A.; Xu, K.; Shin, Y. S.; Tseng, H.-R.; Stoddart, J. F.; Heath, J. R. Nature 2007, 445, 414-417.

2. Molecular Catenanes Rotaxanes and Knots; Sauvage, J.-P., Dietrich-Buchecker, C., Eds.; VCH-Wiley: Weinheim, 1999.

3. (a) Molecular Switches; Feringa, B. L., Ed.; Wiley-VCH: Weinheim, 2001; (b) Elizarov, A. M.; Chiu, S.-H.; Stoddart, J. F. J. Org. Chem. 2002, 67, 91759181; (c) Huang, F.; Switek, K. A.; Gibson, H. W. Chem. Commun. 2005, 36553657.

4. (a) Fyfe, M. C. T.; Stoddart, J. F. Adv. Supramol. Chem. 1999, 5, 1-53; (b) Cantrill, S. J.; Pease, A. R.; Stoddart, J. F. J. Chem. Soc., Dalton Trans. 2000, 3715-3734; (c) Clifford, T.; Abushamleh, A.; Busch, D. H. Proc. Natl. Acad. Sci. U.S.A. 2002, 99, 4830-4836; (d) Gibson, H. W.; Yamaguchi, N.; Jones, J. W. J. Am. Chem. Soc. 2003, 125, 3522-3533; (e) Arico, F.; Badjic, J. D.; Cantrill, S. J.; Flood, A. H.; Leung, K. C.-F.; Liu, Y.; Stoddart, J. F. Top. Curr. Chem. 2005, 249, 203-259; (f) Griffiths, K. E.; Stoddart, J. F. Pure Appl. Chem. 2008, 80, 485-506.

5. (a) Loeb, S. J.; Wisner, J. A. Chem. Commun. 1998, 2757-2758; (b) Hoffart, D. J.; Loeb, S. J. Angew. Chem., Int. Ed. 2005, 44, 901-904; (c) Vella, S. J.; Tiburcio, J.; Loeb, S. J. Chem. Commun. 2007, 4752-4754.

6. (a) Allwood, B. L.; Spencer, N.; Shahriari-Zavareh, H.; Stoddart, J. F.; Williams, D. J. J. Chem. Soc., Chem. Commun. 1987, 1064-1066; (b) Asakawa, M.; Ashton, P. R.; Ballardini, R.; Balzani, V.; Belohradsky, M.; Gandolfi, M. T.; Kocian, O.; Prodi, L.; Raymo, F. M.; Stoddart, J. F.; Venturi, M. J. Am. Chem. Soc. 1997, 119, 302310; (c) Miljanic, O. S.; Stoddart, J. F. Proc. Natl. Acad. Sci. U.S.A. 2007, 104, 12966-12970; (d) Huang, F.; Jones, J. W.; Gibson, H. W. J. Org. Chem. 2007, 72, 6573-6576; (e) Wang, F.; Han, C.; He, C.; Zhou, Q.; Zhang, J.; Wang, C.; Li, N.; Huang, F. J. Am. Chem. Soc. 2008, 130, 11254-11255.

7. Huang, Y.-L.; Hung, W.-C.; Lai, C.-C.; Liu, Y.-H.; Peng, S.-M.; Chiu, S.-H. Angew. Chem., Int. Ed. 2007, 46, 6629-6633.
8. (a) Cheng, P.-N.; Hung, W.-C.; Chiu, S.-H. Tetrahedron Lett. 2005, 46, 4239-4242; (b) Cheng, P.-N.; Huang, P.-Y.; Li, W.-S.; Ueng, S.-H.; Hung, W.-C.; Liu, Y.-H.; Lai, C.-C.; Peng, S.-M.; Chao, I.; Chiu, S.-H. J. Org. Chem. 2006, 71, 2373-2383; (c) Cheng, K.-W.; Lai, C.-C.; Chiang, P.-T.; Chiu, S.-H. Chem. Commun. 2006, 28542856; (d) Chiu, C.-W.; Lai, C.-C.; Chiu, S.-H. J. Am. Chem. Soc. 2007, 129, 35003501; (e) Hsueh, S.-Y.; Cheng, K.-W.; Lai, C.-C.; Chiu, S.-H. Angew. Chem., Int. Ed. 2008, 47, 4436-4439.

9. Bisson, A. P.; Lynch, V. M.; Monahan, M.-K. C.; Anslyn, E. V. Angew. Chem., Int Ed. 1997, 36, 2340-2342.

10. Connors, K. A. Binding Constants; Wiley: New York, 1987.

11. CCDC 703716 and 703717 contain the supplementary crystallographic data for $[\mathbf{1} \supset \mathrm{DBA}]\left[\mathrm{PF}_{6}\right]$ and 5, respectively. These data can be obtained free of charge from The Cambridge Crystallographic Data Centre via www.ccdc.cam.ac.uk/ data_request/cif.

12. Crystal data for $[\mathbf{1} \supset \mathrm{DBA}][\mathrm{DBA}]\left[2 \mathrm{PF}_{6}\right]:\left[\mathrm{C}_{55} \mathrm{H}_{61} \mathrm{~N}_{5} \mathrm{O}_{5}\right]\left[\mathrm{PF}_{6}\right]_{2} ; \quad M_{\mathrm{r}}=1162.03$; triclinic; space group $P \overline{1} ; \quad a=11.1624(4) ; \quad b=13.2258(5) ; \quad c=19.4664(7) \AA$ $V=2797.18(18) \AA^{3} ; \quad \rho_{\text {calcd }}=1.380 \mathrm{~g} \mathrm{~cm}^{-3} ; \quad \mu(\mathrm{Mo} \quad \mathrm{K} \alpha)=0.169 \mathrm{~mm}^{-1} ; \quad T=$ 295(2) K; colorless needle; 10,657 independent measured reflections; $F^{2}$ refinement; $R_{1}=0.0764 ; w R_{2}=0.1775$.

13. For more details of this synthetic method, see: Hung, W.-C.; Liao, K.-S.; Y.-H. Liu; Peng, S.-M.; Chiu, S.-H. Org. Lett. 2004, 6, 4183-4186.

14. Data for 3-H.PF $:$ : Mp 91-93 ${ }^{\circ} \mathrm{C} ;{ }^{1} \mathrm{H}$ NMR $\left(400 \mathrm{MHz}, \mathrm{CD}_{3} \mathrm{SOCD}_{3}\right): 0.88(\mathrm{t}, J=7 \mathrm{~Hz}$ $12 \mathrm{H}), 1.29-1.38(\mathrm{~m}, 8 \mathrm{H}), 1.51-1.58(\mathrm{~m}, 8 \mathrm{H}), 2.47(\mathrm{br}, 4 \mathrm{H}), 3.32(\mathrm{br}, 4 \mathrm{H}), 3.58$ (br, $4 \mathrm{H}), 3.75-3.89(\mathrm{~m}, 8 \mathrm{H}), 3.90-3.95(\mathrm{~m}, 4 \mathrm{H}), 4.24(\mathrm{~s}, 4 \mathrm{H}), 4.62(\mathrm{~d}, J=6 \mathrm{~Hz}$, $4 \mathrm{H}), 5.41-5.47(\mathrm{~m}, 2 \mathrm{H}), 6.76(\mathrm{~d}, J=8 \mathrm{~Hz}, 4 \mathrm{H}), 6.96(\mathrm{~d}, J=8 \mathrm{~Hz}, 4 \mathrm{H}), 6.99(\mathrm{~d}$, $J=8 \mathrm{~Hz}, 4 \mathrm{H}), 7.12(\mathrm{~d}, J=8 \mathrm{~Hz}, 4 \mathrm{H}), 7.33(\mathrm{br}, 2 \mathrm{H}), 8.33(\mathrm{t}, J=7 \mathrm{~Hz}, 1 \mathrm{H}), 8.40(\mathrm{~d}$, $J=7 \mathrm{~Hz}, 2 \mathrm{H}), 9.82$ (br, $2 \mathrm{H}) ;{ }^{13} \mathrm{C}$ NMR $\left(100 \mathrm{MHz}, \mathrm{CD}_{3} \mathrm{OD}\right): 14.2,20.1,33.7$ $\left(J_{\mathrm{PC}}=7 \mathrm{~Hz}\right), 43.3,45.5,52.1,67.6\left(J_{\mathrm{PC}}=6 \mathrm{~Hz}\right), 70.8,71.8,75.3,126.6,128.4$, 129.6, 129.9, 130.7, 130.9, 136.4, 141.0, 141.8, $143.0\left(J_{\mathrm{PC}}=5 \mathrm{~Hz}\right), 150.2,165.3$; ${ }^{31} \mathrm{P}$ NMR (162 MHz, $\mathrm{CD}_{3} \mathrm{OD}$ ): -138.5 (septet, $J=707 \mathrm{~Hz}, \mathrm{PF}_{6}{ }^{-}$), 15.1; HRMS (ESI): $m / z$ calcd for $[3-\mathrm{H}]^{+}\left(\mathrm{C}_{59} \mathrm{H}_{85} \mathrm{~N}_{6} \mathrm{O}_{11} \mathrm{P}_{2}\right)$ 1115.5752; found 1115.5811 .

15. (a) Furusho, Y.; Matsuyama, T.; Takata, T.; Moriuchib, T.; Hirao, T. Tetrahedron Lett. 2004, 45, 9593-9597; (b) Fuller, A.-M.; Leigh, D. A.; Lusby, P. J.; Oswald, I. D. H.; Parsons, S.; Walker, D. B. Angew. Chem., Int. Ed. 2004, 43, 3914-3918.

16. Crystal data for 5: $\left[\mathrm{C}_{34} \mathrm{H}_{36} \mathrm{~N}_{4} \mathrm{O}_{5} \mathrm{Pd} \cdot \mathrm{H}_{2} \mathrm{O}\right]\left[\mathrm{PF}_{6}\right] ; M_{\mathrm{r}}=705.08$; monoclinic; space group $P 2_{1} / n ; a=12.4078(2) ; b=9.3147(1) ; c=28.1577(3) \AA ̊ \quad V=2194.10(7)$

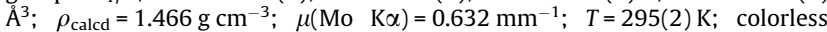
needle; 7303 independent measured reflections; $F^{2}$ refinement; $R_{1}=0.0378$; $w R_{2}=0.0841$.

17. Data for 9: Mp 247-249 ${ }^{\circ} \mathrm{C}$; ${ }^{1} \mathrm{H}$ NMR $\left(400 \mathrm{MHz}, \mathrm{CDCl}_{3}\right)$ : $3.50-3.52(\mathrm{~m}, 4 \mathrm{H})$, $3.60-3.63(\mathrm{~m}, 4 \mathrm{H}), 4.28(\mathrm{~s}, 4 \mathrm{H}), 4.34(\mathrm{~s}, 4 \mathrm{H}), 4.86(\mathrm{~s}, 4 \mathrm{H}), 6.61(\mathrm{~d}, J=8 \mathrm{~Hz}, 4 \mathrm{H})$, $6.85(\mathrm{~d}, J=8 \mathrm{~Hz}, 4 \mathrm{H}), 7.13-7.18(\mathrm{~m}, 12 \mathrm{H}), 7.19-7.22(\mathrm{~m}, 24 \mathrm{H}), 7.30(\mathrm{~d}, J=8 \mathrm{~Hz}$, $4 \mathrm{H}), 7.42(\mathrm{t}, J=8 \mathrm{~Hz}, 1 \mathrm{H}), 7.48-7.51(\mathrm{~m}, 3 \mathrm{H}), 7.81(\mathrm{br}, 2 \mathrm{H}) ;{ }^{13} \mathrm{C}$ NMR $(100 \mathrm{MHz}$ $\left.\mathrm{CDCl}_{3}\right): 29.8,50.2,52.9,64.5,68.3,70.2,73.5,82.9,92.2,117.4,124.2,125.7$ $127.3,127.4,128.9,130.8,131.5,135.1,135.6,137.8,140.1,140.3,141.7,143.9$, 146.7, 152.2, 152.8, 171.0; HRMS (FAB): $m / z$ calcd for $[9]^{+}\left(\mathrm{C}_{90} \mathrm{H}_{74} \mathrm{~N}_{6} \mathrm{O}_{9} \mathrm{Pd}\right)$ 1488.4552; found 1488.4597. For more details of this synthetic method, see Ref. 15a.

18. We were unable to remove the $\mathrm{Pd}(\mathrm{II})$ ion from the [2]rotaxane $\mathbf{9}$ when using catalytic hydrogenolysis $(\mathrm{Pd} / \mathrm{C})$, hydrolysis under acidic $(\mathrm{HCl})$ and basic $\left(\mathrm{Et}_{3} \mathrm{~N}\right)$ conditions, or high-pressure carbon monoxide (50 atm), suggesting that relatively tight binding occurs between the components and supporting the integrity of the purposed rotaxane-like molecular structure. 